USAWC STRATEGY RESEARCH PROJECT

\title{
UNITED STATES SPECIAL OPERATIONS COMMAND STRATEGIC ISSUES FOR THE LONG WAR
}

\author{
by \\ Lieutenant Colonel Joseph T. Wiley \\ United States Air Force
}

\author{
Dr. Jeffrey L. Groh \\ Project Adviser
}

\begin{abstract}
This SRP is submitted in partial fulfillment of the requirements of the Master of Strategic Studies Degree. The U.S. Army War College is accredited by the Commission on Higher Education of the Middle States Association of Colleges and Schools, 3624 Market Street, Philadelphia, PA 19104, (215) 662-5606. The Commission on Higher Education is an institutional accrediting agency recognized by the U.S. Secretary of Education and the Council for Higher Education Accreditation.

The views expressed in this student academic research paper are those of the author and do not reflect the official policy or position of the Department of the Army, Department of Defense, or the U.S. Government.
\end{abstract}

U.S. Army War College

CARLISLE BARRACKS, PENNSYLVANIA 17013 


\section{Report Documentation Page}

Form Approved

OMB No. 0704-0188

Public reporting burden for the collection of information is estimated to average 1 hour per response, including the time for reviewing instructions, searching existing data sources, gathering and maintaining the data needed, and completing and reviewing the collection of information. Send comments regarding this burden estimate or any other aspect of this collection of information,

including suggestions for reducing this burden, to Washington Headquarters Services, Directorate for Information Operations and Reports, 1215 Jefferson Davis Highway, Suite 1204, Arlington

VA 22202-4302. Respondents should be aware that notwithstanding any other provision of law, no person shall be subject to a penalty for failing to comply with a collection of information if it

does not display a currently valid OMB control number.

\begin{tabular}{|c|c|c|}
\hline $\begin{array}{l}\text { 1. REPORT DATE } \\
\mathbf{1 5} \text { MAR } 2006\end{array}$ & 2. REPORT TYPE & 3. DATES COVERED \\
\hline \multirow{3}{*}{\multicolumn{2}{|c|}{$\begin{array}{l}\text { 4. TITLE AND SUBTITLE } \\
\text { United States Special Operations Command Strategic Issues for the Long } \\
\text { War }\end{array}$}} & 5a. CONTRACT NUMBER \\
\hline & & 5b. GRANT NUMBER \\
\hline & & 5c. PROGRAM ELEMENT NUMBER \\
\hline \multirow{3}{*}{\multicolumn{2}{|c|}{$\begin{array}{l}\text { 6. AUTHOR(S) } \\
\text { Joseph Wiley }\end{array}$}} & 5d. PROJECT NUMBER \\
\hline & & 5e. TASK NUMBER \\
\hline & & 5f. WORK UNIT NUMBER \\
\hline \multicolumn{2}{|c|}{$\begin{array}{l}\text { 7. PERFORMING ORGANIZATION NAME(S) AND ADDRESS(ES) } \\
\text { U.S. Army War College,Carlisle Barracks,Carlisle,PA,17013-5050 }\end{array}$} & $\begin{array}{l}\text { 8. PERFORMING ORGANIZATION } \\
\text { REPORT NUMBER }\end{array}$ \\
\hline \multirow{2}{*}{\multicolumn{2}{|c|}{ 9. SPONSORING/MONITORING AGENCY NAME(S) AND ADDRESS(ES) }} & 10. SPONSOR/MONITOR'S ACRONYM(S) \\
\hline & & $\begin{array}{l}\text { 11. SPONSOR/MONITOR'S REPORT } \\
\text { NUMBER(S) }\end{array}$ \\
\hline
\end{tabular}

12. DISTRIBUTION/AVAILABILITY STATEMENT

Approved for public release; distribution unlimited.

13. SUPPLEMENTARY NOTES

14. ABSTRACT

See attached.

15. SUBJECT TERMS

16. SECURITY CLASSIFICATION OF:

a. REPORT

unclassified b. ABSTRACT

unclassified c. THIS PAGE unclassified
17. LIMITATION OF ABSTRACT

\begin{tabular}{c|l}
$\begin{array}{c}\text { 18. NUMBER } \\
\text { OF PAGES }\end{array}$ & 19a. NAME OF \\
$\mathbf{2 6}$ & RESPONSIBLE PERSON \\
& \\
\hline
\end{tabular}




\section{ABSTRACT}

AUTHOR: $\quad$ Lieutenant Colonel Joseph T. Wiley

TITLE: $\quad$ United States Special Operations Command Strategic Issues for the Long War

FORMAT: $\quad$ Strategy Research Project

DATE: $\quad 15$ March $2006 \quad$ WORD COUNT: $7302 \quad$ PAGES: 26

KEY TERMS: $\quad$ Strategy, NSC, Globalization

CLASSIFICATION: Unclassified

Within the United States military, the Secretary of Defense has designated the United States Special Operations Command (USSOCOM) as the supported combatant command in the "Global War on Terrorism." However, the scope of the national strategy is vastly beyond simply implementing a campaign plan for Special Operations Forces (SOF) to "send handfuls of heroes on desperate ventures." ${ }^{3}$ Recognition of USSOCOM's strengths and weaknesses is critical. For the United States military, and ultimately USSOCOM, to effectively combat global terrorism, military strategic planners need to understand three major issues. These issues are the strengths and weaknesses of the strategies defining the fight against terrorism; the executive branch interagency environment and the structure required to develop and implement strategy; and an understanding of the global political environment in which the strategies will be implemented. This paper will investigate these three issues to develop and implement the strategies that form the foundation for USSOCOM's campaign plan. 



\section{UNITED STATES SPECIAL OPERATIONS COMMAND STRATEGIC ISSUES FOR THE LONG WAR}

World order is more fundamental and primordial than international order because the ultimate units of the great society of all mankind are not states (or nations, tribes, empires, classes or parties) but individual human beings, which are permanent and indestructible in a sense in which groupings of them of this or that sort are not. This is the moment for international relations, but the question of world order arises whatever the political or social structure of the globe. ${ }^{1}$

- Hedley Bull

In response to the September 11, 2001 terrorist attacks against targets inside the United States, the Bush administration issued a revised security document, The National Security

Strategy of the United States and a new document, The National Strategy for Combating Terrorism. Together, the policy documents describe a broad and aggressive effort to disrupt and destroy the ability of terrorist organizations to operate in the international environment. "The intent of the national strategy is to stop terrorist attacks against the United States, its citizens, its interests, and our friends and allies around the world and ultimately, to create and international environment inhospitable to terrorists and all those who support them."2

Within the United States military, the Secretary of Defense has designated the United States Special Operations Command (USSOCOM) as the supported combatant command in the "Global War on Terrorism."3 However, the scope of the national strategy is vastly beyond simply implementing a campaign plan for Special Operations Forces (SOF) to send "handfuls of heroes on desperate ventures."4 Recognition of our own strengths and weaknesses is critical. For the United States military, and ultimately USSOCOM, to effectively combat global terrorism, military strategic planners need to understand three major issues. These issues are the strengths and weaknesses of the strategies defining the fight against terrorism; the executive branch interagency environment and the structure required to develop and implement strategy; and an understanding of the global political environment in which the strategies will be implemented. This paper will investigate these three issues to develop and implement the strategies that form the foundation for USSOCOM's campaign plan.

Understanding the first issue is about embracing the need for a multilayered strategy that requires the use of all the elements of national power. Any type of strategic or operational success hoped for by unleashing USSOCOM to engage in a long term war on terrorism depends on a campaign coordinated with, and complementary to, symbiotic efforts within the Department of Defense and across the other government departments. Only through 
interagency synchronization, coordination, and cooperation, will the effort provide "the persistent accumulation of successes-some seen, some unseen."

The second issue concerns the structure and responsibility for pursuing the strategy within the executive branch of the government. Despite the establishment of new agencies through legislation and executive order, bureaucratic history and inertia have the possibility of emasculating the concepts of unity of command and effort within the interagency construct. While providing the opportunity to confront terrorism with all of the elements of United States national power, turf wars, lack of bureaucratic initiative and in-fighting about roles or missions can short circuit operational and tactical initiatives.

The third issue is scanning and understanding the future operational environment. The effects of globalization on the international system are undeniable. A clear understanding of the political, economic, and informational environment will enable establishment of benchmarks for measuring progress in the fight against terrorism. It also is the basis for developing a vision for how the United States wants to shape the post-Global War on Terrorism strategic environment. The combination of these two elements gives operational focus to the strategy by giving it purpose and measurements.

\section{Soup to Nuts: Understanding the Elements of the Strategy}

The United States is a big, lumbering, pluralistic, affluent, liberal, democratic, individualistic, materialistic (if not hedonistic), technologically supremely sophisticated society. Our military strategy should, and must be built upon these facts. ${ }^{6}$

—Samuel P. Huntington

Despite tongue in cheek calls by pundits to prepare a National Strategy to Combat the Proliferation of National Strategies ${ }^{7}$, the recent publication of numerous national strategies serves a critical purpose; attempting to ensure the full extent of government policies and programs explicitly support the capstone strategy document, the National Security Strategy of the United States of America (NSS). In particular, the NSS says "the aim of this strategy is help make the world not just safer, but better." ${ }^{n}$ The incredible breadth of this strategic objective demands subordinate strategies nested within the overall goal to achieve a desirable outcome. The methodology of identifying broad strategic goals and relegating specific policy prescriptions to more narrowly focused documents allows the development of coherent implementation efforts based on the involved department's core capability. The linkage of the strategies is critical.

"The strengths of some strategies are useful in suggesting ways to enhance the value of other 
strategies, fill in gaps, speed implementation, guide resource allocations, and provide oversight opportunities."

The United States General Accountability Office (GAO), the Congress's non-partisan investigative agency, conducted a study in which they identified characteristics that are useful examining the effectiveness of a proclaimed strategy. These desirable characteristics are:

- A statement of purpose, scope, and methodology;

- Problem definition and risk assessment;

- Goals, subordinate objectives, activities, and performance measures;

- Resources, investments, and risk management;

- Organizational roles, responsibilities, and coordination;

- Integration and implementation ${ }^{10}$

In addition to these characteristics developed by the GAO, Colin S. Gray advocates that an important characteristic of a strategy is that it must be holistic in its approach. He believes that "a cardinal virtue of strategic theory, reasoning, or planning is that it brings together, it connects, activities which otherwise easily could be treated as though they were autonomous realms."11

To a varying degree, these characteristics bound the scope of the United States approach to pursuing the Global War on Terrorism. The Bush administration recognizes that all of the elements of national power will need to be brought in to play to achieve the goals of the National Security Strategy and the National Strategy for Combating Terrorism. The purposes of these national strategies are to give meaning to the use of the nation's power. "...Whether or not enemy forces actually are destroyed or comprehensively defeated, indeed whether or not success attends our arms, tactical activity must have strategic effect. ${ }^{12}$

Examining the strategy documents that guide the effort to combat terrorism from this framework reveals an effort to incorporate these characteristics into a layered approach that can guide operations against terrorist organizations. Section III of the NSS lays out the goal to "Strengthen Alliances to Defeat Global Terrorism and Work to Prevent Attacks against Us and Our Friends." ${ }^{\text {"13 }}$ Although the document proclaims explicitly that "the enemy is terrorism premeditated, politically motivated violence perpetrated against innocents," ${ }^{, 14}$ it also sets a first priority "to disrupt and destroy terrorist organizations of global reach..."15 Ironically, although clearly the group that shaped the September 2002 NSS document, Al-Qaeda is only mentioned once in the NSS, and then only in the context of the battlefield defeat in Afghanistan. Ambiguity about the enemy at this level is certainly intentional. While Al-Qaeda is a specific operational and tactical objective; the strategic goal is defeating terrorism in general. More specific 
prescriptions of who the enemy organizations are is left to the National Strategy for Combating Terrorism published in February 2003.

The National Strategy for Combating Terrorism is an expansion and explanation of Section III of the NSS. This strategy document seeks to "hang some meat on the bones" at the strategic level. This is the first level of strategic documents that is directive in the nature of the goals. The document describes specific objectives laid out to meet the overall strategic intent. The Departments of Defense and State, the Intelligence Community, and all government agencies are formally tasked to produce specific plans and conduct annual reviews. ${ }^{16}$ All of these organizations are charged with meeting the intent to:

Stop terrorist attacks against the United States, its citizens, its interests, and our friends and allies around the world and ultimately, to create an international environment inhospitable to terrorists and all those who support them. ${ }^{17}$

The National Security Strategy for Combating Terrorism also further refines the desired end state by graphically depicting the current status of the global terrorism threat, and then moving to a condition where terrorism is "unorganized, localized, non-sponsored, rare, and where the measure of success is returning terrorism to the "Criminal Domain."'18 Those charged with implementing the strategy are given a fairly explicit measuring stick for determining if they are making progress or if they have achieved this end.

The National Strategy for Combating Terrorism also provides other key strategic elements. In addition to the policy elements describing the desired end state, the strategy provides a method for moving the ideas into operation. To give operational focus to the strategy, the document provides a set of goals and objectives required to implement the strategy. The strategy is defined by a "4D (Defeat, Deny, Diminish, and Defend) effort." ${ }^{19}$ Each of these main goals is further expanded with 2-5 specific objectives representing the opportunity to conduct a holistic, cross-functional campaign utilizing all of the elements of national power. As an example, under the goal of "Defeat Terrorists and Their Organizations" ${ }^{\text {"20 }}$, the three objectives are to:

- Identify terrorists and terrorist organizations.

- Locate terrorists and their organizations.

- Destroy terrorists and their organizations.

Each of the objectives listed under the goal is amplified to indicate which elements of the government shares responsibility i.e., defense, intelligence, law enforcement. As a result of this national strategic guidance, the executive agencies, such as the Department of Defense, 
Department of Justice, and the intelligence community, should plan and execute operations, program resources and prioritize efforts based on the specific guidance in the document.

Drawing from this effort, and seeking to further clarify its roles and responsibilities in the government-wide effort to combat terrorism, the Department of Defense (DoD) took the strategies to a more specific focus. The Department of Defense produced an updated National Military Strategic Plan for the War on Terrorismin February 2006. Although the original March 2005 document was classified the new document has an unclassified portion. Department of Defense officials have discussed portions of the strategic plan with journalists. One of the important elements of the plan is:

The terrorist threat against the United States is now defined as "Islamist extremism"-not just al Qaeda. The Pentagon document identifies the "primary enemy" as "extremist Sunni and Shia movements that exploit Islam for political ends" and that form part of a global web of enemy networks." Recognizing that al-Qaeda's influence has spread, the United States is now targeting some two dozen groups-a significant change from the early focus on just al-Qaeda and its leadership. ${ }^{22}$

In addition to a new definition of the enemy, the plan designates the United States Special Operations Command (USSOCOM) to "draft a global campaign plan that will detail the new counter-terrorism operations to be launched and to 'synchronize' the counter-terrorism plans of the five geographic military commands." ${ }^{23}$ In a similar manner to the National Strategy for Combating Terrorism, the DoD strategic plan further breaks the large elements into smaller, more manageable areas. The plan:

Directs military commanders to go after a list of eight pressure points at which the terrorist groups could be vulnerable: ideological support, weapons, funds, communications and movement, safe havens, foot soldiers, access to targets, and leadership. ${ }^{24}$

The appointment by the Secretary of Defense of USSOCOM to synchronize the National Military Strategic Plan for the War on Terrorism recognizes the importance of SOF's professionalism in executing its core tasks, including counterterrorism, counterproliferation, unconventional warfare and others, in achieving the strategic plan's goals. ${ }^{25}$ This set of core tasks is the final element that links the National Security Strategy through the subordinate National Strategy for Combating Terrorism and the National Military Strategic Plan for the War on Terrorism to the forces that will use tactical skills to affect the broad strategy. However, Lieutenant General Dell L. Dailey, Director of the Center for Special Operations, U.S. Special Operations Command, clearly understands that military operations are not the singular answer 
to defeating global terrorism. General Dailey lays down the marker when he stated in Joint

Forces Quarterly that:

First, DoD must conduct operations in support of the larger U.S. Government-led effort to prevent the emergence of new terrorist threats against the United States and its interests. Done properly, these actions minimize combat engagements. Our goal is to make the local conditions untenable for terrorists through focused engagement with like-minded nations to address the conditions that allow terrorism to emerge. ${ }^{26}$

Today, elements of USSOCOM are conducting tactical operations from each of these core task areas as part of an effort that can be directly tied to the National Security Strategy. The linkage of ongoing operations in the Philippines, the Horn of Africa and Afghanistan to the NSS is derived from the National Military Strategic Plan for the War on Terrorism. However, the National Military Strategic Plan for the War on Terrorism also appears to have some shortcomings. It seems to suffer from the "who's really in charge" problem. Although USSOCOM has been designated as the lead combatant command for developing the global campaign plan, each of the five geographic combatant commands has the responsibility to execute the campaign. This division of effort is a self-inflicted seam that will need to be monitored to ensure it is not detracting from the overall DoD contribution to countering global terrorism.

Although USSOCOM is "tasked to synchronize the global counterterrorism campaign plan and conduct preparatory reconnaissance missions against terrorist organizations around the world, ${ }^{, 27}$ the effort it still left to the geographical combatant commanders to implement. At all levels of the strategies to combat terrorism, there is recognition of the global nature of the terrorist organizations the U.S. is fighting. The terrorist groups do not operate along the lines of the unified command plan that defines the boundaries of the geographic combatant commanders, ${ }^{28}$ yet implementation of a global campaign is defined by those boundaries.

If the U.S. military is going to effectively implement the National Military Strategic Plan for the War on Terrorism, further authority needs to be granted to USSOCOM. The command should go beyond being just a synchronizer of the campaign plan. USSOCOM should be given the authority to direct all SOF forces worldwide in the effort to implement the plan. Currently, the Theatre Special Operations Commands, or T-SOCs, and their assigned forces belong to the geographic combatant commander as a sub-unified command. USSOCOM is not in the operational command chain for these forces. USSOCOM is only the force provider. Although USSOCOM is the synchronizer of the National Military Strategic Plan for the War on Terrorism, 
the geographical combatant commander's staff is placed between USSOCOM and the T-SOC. Speed, agility and unity of action in the War on Terrorism are sacrificed.

To remedy this glaring shortfall, the T-SOCs and all of the forward based SOF units should be placed under the operational control of USSOCOM through a revision of the unified command plan. These forces would continue to support the geographical combatant commander's operational plans, but would not fall under his operational control until those plans are activated or as tasked by the Secretary of Defense. This action will optimize the Defense Department's command structure for the War on Terrorism and maintain the capability of SOF to support the geographic combatant commander's war fighting requirements.

The Nature of the Strategy: Prevention, Deterrence and Preemption

In his classic strategic tome "On War", Carl Von Clausewitz states "...the most far reaching act of judgment the statesman and commander have to make is to establish by that test the kind of war on which they are embarking; neither mistaking it for, not trying to turn it into, something that is alien to its nature. ${ }^{229}$ A strategy cannot be effective if there is not clarity of goals and purpose to provide focus for political objectives. For USSOCOM, this clarity is required in order to balance the campaign between kinetic and non-kinetic actions, to synchronize activities with other government agencies and to ensure proper use of finite resources.

The policy guidance for a long, sustained fight against global terrorism is consistently laid out through the series of previously discussed documents, giving direction from the strategic to the operational levels of campaigning. However, the tools in the hand of the administration to prosecute an extended campaign against global terrorism are quite different from the ones available and effective during the Cold War. The NSS states "it has taken us almost a decade for us to comprehend the true nature of this new threat. Given the goals of rogue states and terrorists, the United States can no longer solely rely on a reactive posture..." ${ }^{30}$

Specifically in the areas of terrorism and weapons of mass destruction (WMD), the administration believes that a deterrence based policy is not viable as a stand alone strategy. "An enemy that has no territory to protect and whose forces crave martyrdom will not be deterred by threats of retaliation." ${ }^{11}$ Terrorist organizations, by their nature, are fundamentally immune to deterrence. Colin Gray points out "that deterrence, unlike defense, is voluntary. An intended deterree may by unwilling, or unable, to be deterred. No excellence at deterrence can guarantee successful deterrent effect." ${ }^{32}$ 
The administration and other security professionals are also certain that terrorist organizations will attempt to conduct devastating attacks against the United States and its friends and allies in the future. Former Congressman Lee Hamilton, Vice Chairman of the 9/11 Commission, believes that the United States has done a good job at protecting itself since the September 11, 2001 terrorist attacks, "but we should not take false comfort.... It is not likely that we will ever eliminate terrorism.... People will always commit acts of violence; someone will always want to do us harm."33

To acknowledge this assessed volatility and uncertainty in international conditions, the Bush administration signaled a significant, but controversial, policy change in how the United States intends to confront security issues. In articulating the National Security Strategy in 2002 and the National Strategy for Combating Terrorism in 2003, the administration moved the concept of preemption from an implied option to an explicit one. While arguing that the policy of preemption is based on long standing international law criteria, the cornerstone of the policy is based on "the existence of an imminent threat." 34 However,

while the National Security Strategy sensibly refrains from setting down rigid criteria for when preemptive military action should be considered or used, its reticence to elaborate the general conditions and circumstances, or the factors to be weighed in deciding to use force, has failed to resolve uncertainty regarding administration decision-making when faced with difficult future situations. ${ }^{35}$

The definition of imminent threat is critical to making the National Security Strategy and the National Strategy for Combating Terrorism viable instruments for implementing the national policy and defining the manner USSOCOM forces are used to implement the strategy. The National Security Strategy says the United States must "adapt the concept of imminent threat to the capabilities and objectives of today's adversaries." ${ }^{\prime 6}$ Using Just War theory, "...preemption builds on a conviction that using armed force is just when based on partial but sufficient evidence of a clear, unpredictable, and volatile danger... Redefining imminent, as called for in the National Security Strategy, may mean a clear danger in not necessarily a present danger." ${ }^{37}$ For USSOCOM, this may mean the administration will place more emphasis on direct action, and less on unconventional warfare.

Keeping an Eye on the Strategic Target

Based on the number of strategic documents produced, the administration has made a concerted effort to develop a comprehensive strategy to combat global terrorism. However, the nature of the United States' strategy is not clear to many. Robert Kagan believes that, "many Europeans and others around the world, insist the American willingness to take preventive 
action is the prime example of the superpower's disregard for international law and international order..."38 In the July/August 2004 Cato Institute Policy Report, Charles V. Pena argues that the Iraq War is "a quixotic quest that does not focus on the group responsible for the September 11 attacks. ${ }^{139}$ He goes further, criticizing the Iraq War in the same article as a distraction from the War on Terrorism that resulted from faulty "logic that led the Bush Administration to wage war against Iraq even though the White House has conceded that Saddam Hussein had nothing to do with 9/11 and its allegations of linkages between the former regime and AI Qaeda are not conclusively proven. ${ }^{40}$

Many commentators doubt whether there is a linkage of the War on Terrorism with war in Iraq and the administration's use of the theory of preemption to justify it. While no credible source from either side of the political spectrum has proposed an alternative to administration's strategy for the War on Terrorism as a whole, the Iraq War has been a lightning rod of political divisiveness. The constant criticism that President Bush's administration is taking for the conduct of the war in Iraq from domestic political opponents and long-time allies' result from spirited debate over the validity of the connection of the Iraq War to the War on Terrorism, and the argument of preventive war versus preemptive war.

Administration critics such as Michael O'Hanlon and Susan Rice from the Brookings Institute warn that the use of preemption or prevention theory to justify the war in Iraq, "...reinforces the image of the United States as too quick to use military force and to do so outside the bounds of international law and legitimacy. ${ }^{41}$ But this may not be the root cause of the diplomatic squabbles with friends and allies over U.S. policies and strategies for the campaign against global terrorism. Robert Kagan believes that:

The real issue may not be prevention itself but who is doing the preventing, and who gets to decide when and where preventive war occurs. In this, what Europeans object to is not so much American actions, but what they consider the "unilateralism" of American actions. The dispute over preventive war is really little more than a recapitulation of the central uni-polar predicament: How will the sole superpower be controlled? ${ }^{42}$

Given the international holistic effort that is needed to combat global terrorism, this perception makes the implementation of the United States' strategy problematic. USSOCOM requires indepth cooperation from friends and allies to implement the strategy and campaign for the war on terrorism. It is imperative that the perceptions and suspicions of the use of American power are adequately addressed by the administration to enable USSOCOM to prosecute the campaign against global terrorism. 
Indecision May or May Not be My Problem: The National Security Council and the Interagency

The second main issue concerns the structure and responsibility for pursuing the strategy within the executive branch of the government. If the Iraq War is taken out of the equation, there appears to be great consensus for the overall strategy for the War on Terrorism within both major political parties and among the traditional allies. However, even though it appears to be generally supported, the National Strategy for Combating Terrorism contains several seams that are potential failure points. At the strategic level of the United States government, the interagency level, the question of who has direct responsibility for implementation has not yet been completely answered. This, despite the fact that,

...not only is the United States working more aggressively to defeat terrorists and deny them sanctuary, it is also focused on the need to address the societal conditions that provide fertile ground for terrorism. This broader approach to counterterrorism requires the application and integration of a much wider range of instruments of national power than has been used in the past. ${ }^{43}$

Interagency consensus and coordination is required to make the counterterrorism strategy work. Without the cooperation of other government agencies such as the State Department and the Central Intelligence Agency, the USSOCOM campaign plan cannot be effective. The National Military Strategic Plan for the Global War on Terrorism's foundation is interagency effort and cooperation. However, even some of the most powerful Beltway insiders acknowledge weaknesses in the system. Current National Security Advisor Stephen Hadley, "cites a dictum of former NSC colleague Bob Blackwill: "In any interagency meeting, what often gets lost is what we're trying to accomplish." 44 In defense of those participating in the interagency effort, part of the problem is in a unity of effort. Currently, there are four counterterrorism directives in effect.

Two are from the Clinton era; two were signed by President Bush. Clinton's Presidential Decision Directive 39, signed in 1995, for example, gives the State Department the lead role in counterterrorism efforts abroad, but after 9/11, President Bush gave the CIA the lead for disrupting terrorist networks overseas. National Security Presidential Directive 9, signed on Oct. 25, 2001, directs the Pentagon to prepare military plans for eliminating terrorist sanctuaries. Similar overlapping jurisdictions exist for the Justice Department, the Department of Homeland Security, and the new intelligence entities created since 9/11. ${ }^{45}$

Without argument, clarification and specific guidance issued from the White House through the National Security Council is required to eliminate the obvious weaknesses to the strategy at the interagency level. The strategic guidance from the National Security Council to the executive branch of the government should leave no question at the national level which agency or department has the primary responsibility for accomplishing the four main goals and 
subordinate objectives of the National Strategy for Combating Terrorism. Fixing glaring

deficiencies such as the one illustrated here should be an immediate priority for the

administration. Without a clear path to cogent decision-making, USSOCOM's implementation of the national strategy will be difficult at best.

But clarification of Presidential Directives is not enough. By legislative design, the starting point for implementing a successful national strategy is supposed to be the National Security Council. Established by the National Security Act of 1947, the specific structure of the National Security Council is determined by each President. According to the current White House website,

The National Security Council is the President's principal forum for considering national security and foreign policy matters with his senior national security advisors and cabinet officials. Since its inception under President Truman, the function of the Council has been to advise and assist the President on national security and foreign policies. The Council also serves as the President's principal arm for coordinating these policies among various government agencies. $^{46}$

However, inside the capital beltway, only holding the authority to coordinate makes you a welterweight boxer in the ring with the heavyweight champion, your just don't have the punching power to last through long rounds of interagency sparring. While the National Security Council is tasked to give advice to the President, "critics contend that it has neither the charter not the authority to mandate interdepartmental cooperation. ${ }^{n 7}$ Indeed, "the view that the Councils role was to foster collegiality among departments also gave way to the need by successive Presidents to use the Council as a means of controlling and managing competing departments." ${ }^{48}$

Because of these realities about the role and the authorities of the National Security Council, the NSC is often focused on handling the issue at hand rather than the over the horizon problems. "Some have suggested the President (as well as the Congress) has too frequently become victimized by the "tyranny of the in-box"... robbed of an ability to step back and take a more strategic focus on issues of great complexity... ${ }^{49}$ "In the national security arena, "the tyranny of the inbox" often becomes "the tyranny of managing today's crises."...This understandable focus on today, however, often precludes strategic thinking about tomorrow." The 9/11 Commission Report describes this as a "subtler and more serious danger... as the NSC staff is consumed by these day-to-day tasks, it has less capacity to find the time and detachment needed to advise a president on larger policy issues. ${ }^{51}$

It is arguable that many areas of national security and foreign policy can be addressed through the traditional stove pipe of bureaucratic executive branch methodologies. These areas 
can proceed without interagency coordination because they do not rise to the level of being critical or vital national security issues. However, transnational terrorism poses too agile a threat to be dealt with in less than a comprehensive manner. The constant attention of the vast extent of the interagency arena is required. "In this sense, unity of effort is not just something that is nice to have; it is an imperative." 52 As discussed in previous paragraphs, the National Security Council is not currently empowered or structured to handle this. It is imperative that it structure and authorities are modified to accommodate the realities of the post-Cold War security environment. The focus must shift to longer-term, strategic issues.

Waiting for the Next Explosion: Reactive Versus Prescriptive

The Defense Department is calling its effort to combat global terrorism the Long War. This recognizes the long-term, strategic focus vital to the third portion of the National Strategy for Combating Terrorism's 4-D strategy; "diminishing the underlying conditions terrorists seek to exploit." ${ }^{\prime 3}$ With this leg of the strategy, the United States will attempt to ameliorate the conditions worldwide that feed and support terrorist organizations. Forging meaningful and effective programs to implement this goal will require consistent and long term commitment to solving many incredibly difficult social, economic and informational challenges. Progress will be necessarily slow. Influencing and persuading allies and friends will be the tenets of this effort, supported by long-term, consistent resource allocations. Fully implementing and achieving the goals of the strategy to combat global terrorism will take a long time to accomplish, possibly decades. Long-term vision and consistent policy guidance from the National Security Council will be the linchpin of a successfully implemented campaign by USSOCOM in the war against terrorism.

During military pilot training, students are taught to reach over and wind the clock on the dashboard as the first reaction to an emergency such as and engine fire or malfunction. This is intended to by the student the time to think the problem through, rather than making a rash reaction and compounding the problem. This type of pause for rational thought should be evident at the strategic level of government. "Experts constantly point out that America's adversaries operate on a strategic timeline of years, if not decades..." Un Unlike at the tactical and operational levels of warfare, at the strategic a faster decision cycle is not necessarily a desired trait. Without taking the time to contemplate and reflect, decisions are made faster, but often at the expense of considering second and third order effects. Policy and strategy then become reactive instead of prescriptive. 
Reactive policy and strategy guidance are indications of near-sighted strategy development. In these conditions, preemption of an imminent threat or prevention of a perceived one becomes an attractive policy when your other options have failed and you are short of ideas. In the case of the National Strategy for Combating Terrorism, strategic planning at the NSC's level, instead of reactive crisis management, can give the nation time to use all of the elements of national power time to achieve the strategy's goals. Instead of relying on military power as a last option, diplomatic, economic, and informational elements have a chance to succeed. With imminent threats from terrorist organizations removed through long-term activities, deterrence of threats should move back to the forefront of U.S. policy. Preemption can move back to an implied strategy as "...the logical corollary to the belief that some of today's enemies are not deterrable. ${ }^{, 55}$ However, this can only be gained through comprehensive strategic planning that links the national strategy to the task of implementing the USSOCOM campaign plan.

New Organizations for the War on Terrorism

At the operational level, some tentative progress has been made. The bureaucratic weaknesses exposed by the September 11, 2001 terrorist attacks, and extensively detailed by the National Commission on Terrorist Attacks upon the United States (9/11 Commission), highlight the lack of coordination and coherence within the government. ${ }^{56}$ Reacting to these shortcomings, both the Congress and the Bush Administration have taken steps to address the weaknesses. Of particular significance is the Intelligence Reform and Terrorism Prevention Act of 2004 (P.L. 108-458) ${ }^{57}$ and Executive Order (EO) 13358. ${ }^{58}$ Although primarily focused on reforming the Intelligence Community, the act and the executive order also address weaknesses in strategic and operational planning and implementation in the executive branch.

In addition to creating the post of the Director of National Intelligence (DNI), the new public law also codified the existence of the National Counterterrorism Center (NCTC). While organizationally included in the purview of the $\mathrm{DNI}$, the act recognizes the difference between intelligence and operations in respect to execution of counterterrorism policies.

The DNI has authority over the Center's budget and programs and...intelligence joint counterterrorism operations. But, because strategic planning for joint counterterrorism options was viewed and an Executive Branch-wide function, the Act stipulates that the Director of NCTC reports directly to the President with respect to "...planning and progress of joint counterterrorism operations (other than intelligence operations).

The joint counterterrorism operations (other than intelligence) activities that the Director of the NCTC is responsible for reporting the progress of directly to the President are the bread and 
butter activities of the USSOCOM campaign plan to support the National Military Strategic Plan for the Global War on Terrorism. In the realm of counterterrorism, the legislation that created the DNI and the NCTC intends to give the Commander of USSOCOM new and prominent access to the interagency arena and the President through the Director of the NCTC.

However, veteran Washington, D.C. insiders like former Congressman Lee Hamilton believe the Intelligence Reform and Terrorism Prevention Act is only a first step. "Intelligence reform legislation moves us in the right direction, but it is not sufficient. No law is self-executing; the key will be implementation. ${ }^{, 60}$ This seems to be a common perception inside the Capital Beltway. Secretary of Defense Donald Rumsfeld spoke to the 9/11 Commission about this issue.

Recalling the Goldwater-Nichols legislation of 1986, Secretary Rumsfeld reminded us that to achieve better joint capability, each of the armed services had to "give up some of their turf and authorities and prerogatives." Today, he said the executive branch is stove-piped much like the four services were nearly 20 years ago." He wondered if it might be appropriate to ask agencies to "give up some of their existing turf and authority in exchange for a stronger, faster, more efficient government wide effort." ${ }^{\prime 1}$

An alternative to the National Security Council asking the agencies to give up power is for the chief executive to direct it. "The only guaranteed means toward such empowerment throughout the President's cabinet will be through a National Security Presidential Directive." ${ }^{\prime 2}$ It seems that if the National Counterterrorism Center is going to evolve into organization that the legislation intended, the authorities vested in the Director of the NCTC have to be exercised immediately and extensively. If the Director of the NCTC is allowed access to the president to report on the progress of ongoing planning and counterterrorism operations, then the authorities vested in the director by the legislation will be validated. However, if the Director of the NCTC is forced to work his way through the National Security Council apparatus, the bureaucracy will quickly understand there is no real power in the organization. This type of failure will reinforce the culture of bureaucratic infighting and lack of coordination that was highlighted in the 9/11 Commission Report. The recommendations for measured risk taking inherent in USSOCOM's campaign planning will suffocate in endless levels of officials who cannot say yes to an operation, but are powerful enough to say no. Ultimately, it would be a preventable tragedy in the making.

\section{The World May or May Not Be Flat: Democracy and Globalization}

The world may have changed on September 11, 2001, but more likely, the difference is how the United States views the world, and the manner in which the country will engage it. As a 
strategic planner, unless you are a member of a modern-day Luddite sect, the recognition that the world is fundamentally changing in political, economic and informational character since the end of the Cold War is a fundamental tenet. Globalization ${ }^{63}$ is upon us. Whether you agree with all of the postulations of the multitude of authors who populate the genre, is irrelevant. The key element is to understand that change is in the air. This "banana wind" signals a dynamic and uncertain environment lacking the dangerous, but predictable, conditions of the Cold War. For USSOCOM to prosecute a successful campaign against global terrorism, SOF strategic planners and leaders must be comfortable in a profoundly unsettled environment. The implications of the actions taken by USSOCOM in implementing the campaign against global terrorism are immense. USSOCOM campaign planners must actively seek to understand the $2^{\text {nd }}$ and $3^{\text {rd }}$ order effects of the actions to preclude unpleasant strategic surprises.

Author Thomas L. Friedman's description of the world as "flat" is a metaphor for the leveling of economic competition between the developed world and the developing world. The "flattening" of the world he describes in his book, The World is Flat: A Brief History of the Twenty-First Century, accounts for both the phenomenal global economic growth experienced in the last fifteen years, and the source of much of the political unrest. In describing the frustration that some societies feel with the forces of globalization, Friedman says,

One of the unintended consequences of the flat world is that is ...connects people to people much faster than people and cultures can often prepare themselves. Some cultures thrive on the opportunities for collaboration that this global intimacy makes possible. Others are threatened, frustrated, and even humiliated by this close contact, which, among other things, makes it easy for people to see where they stand in the world vis-à-vis everyone else. ${ }^{64}$

"Traditional societies the world over are reeling from the impact of globalization, which arrives wearing the face of American popular culture." ${ }^{\text {"65 }}$ Unfortunately the turbulence of globalization feeds the fire of resentment of Islamic extremism in the Muslim world. "Almost the entire Muslim world is affected by poverty and tyranny. Both of these problems are attributed ...to American economic dominance and exploitation, now thinly disguised as "Globalization." 66

Daniel Benjamin and Steven Simon contend that in many parts of the world,

The United States is resented for its cultural hegemony, global political influence, and overwhelming conventional military power. Its cultural reach threatens traditional values... Its support is cited to explain the power of Israel to oppress Muslims and degrade Islam. American military prowess is used to kill Muslims, as in Iraq, or is withheld to facilitate their extermination, as in Bosnia. ${ }^{67}$

Aiding the spread of democracy as a means to counter global terrorism in parts of the world affected by poverty and tyranny will be a difficult and risk-filled proposition. Jessica Stern 
argues in her "study of religious militants, Terror in the Name of God that "democratization is not necessarily the best way to fight Islamic extremism" because the transition to democracy "has been found to be an especially vulnerable period"68 Indeed, some of the tyrannical governments that govern in most parts of the Arab world are the product of one of the few western ideas to transfer to the region. Ironically, this is embodied by "the only European political model that really worked in the Middle East - that of the one-party state, either in the Nazi or the Communist version..."69 The emergence of democratic forms of government in the developing world has shown signs of taking root. The expression of new found entitlement may cause short-term political fireworks, like the election to the majority in the Palestinian Parliament.

The penetration of instant communications to almost all parts of the world poses another challenge to strategic planners. In no other time in history can a tactical blunder, such as the burning of Taliban bodies by misinformed American soldiers, turn into an instantaneous strategic setback. The rapid dissemination of information creates a unique set of opportunities for success or failure as the United States and its allies seek to separate the terrorist groups from the populations they shelter in. Legitimate stories such as the Herculean relief efforts to render aid to the victims of the tsunami in Indonesia or the earthquake in Pakistan will spread as quickly as pictures of prisoner abuse at Abu Ghraib.

However, in the difficult conditions described in the paragraphs above, there also lies opportunity. Recognizing opportunity in an unfamiliar environment "requires the mobilization of collective will and resources, including all of the elements of national power, as well as the concerted efforts of allies and the private sector." ${ }^{70}$ In the age of globalization, it is critical to use all of the resources available to prevail over a determined enemy in a complex operating environment. USSOCOM planners and leaders must recognize the opportunities and use them as an advantage rather than a limiting factor.

\section{$\underline{\text { Conclusion }}$}

In assessing our progress and success in the campaign against global terrorism, it is useful to recount an exchange between Henry Kissinger and Zhou Enlai "in which Kissinger asked Zhou what he thought about the French Revolution. Zhou replied, "It is too early to tell."

Combating the threat of terrorism against the United States and its friends and allies continues to consume the almost undivided attention of all levels of the government. Four years removed from the catastrophic attacks of September 11, 2001, the War on Terrorism is still only in its beginning stages. The United States has developed a series of plans that draw a direct 
line from the strategy to the task of confronting and combating terrorism. The United States Special Operations Command has been given the task of leading the planning and implementation of the Department of Defense's contribution to the national effort.

To create an effective campaign plan to combat global terrorism, USSOCOM strategic planners need to understand three major issues; the strengths and weaknesses of the strategies defining the fight against terrorism; the executive branch interagency environment and the structure required to develop and implement strategy; and an understanding of the global political environment in which the strategies will be implemented. The arguments in this paper lend credence to the importance of these issues. While the national strategy is illustrated in great detail amongst a web of interlocking documents, the underlying preemptive nature of the strategy must be understood to implement an effective campaign. To effectively use the finite SOF resources in a strategic, global campaign, USSOCOM should assume operational control of all SOF, even those assigned to a geographic combatant commander's area of responsibility. Although complex and cumbersome, the machinations of the interagency process must be mastered by the USSOCOM leaders and planners. The National Security Council should be organized to reach beyond the crisis daily political issues to develop longterm strategies and policies to anchor the campaign against global terrorism. The Director of the NCTC must exercise the authorities embedded in the legislation that created the DNI to have direct access to the President for operational counterterrorism planning and operations.

This avenue is critical for aggressive and agile prosecution of the USSOCOM global campaign. Finally, the realities of a globalizing world must be recognized and accounted for by USSOCOM strategic planners. Although dynamic and seemingly chaotic, the conditions provide opportunities to separate and isolate the roots of terrorism from the conditions it needs to prosper.

With a sound strategy, clear lines of command and responsibility, and an unwavering dedication to the long term nature of the effort, the United States can prevail in the War on Terrorism. USSOCOM will not surrender the initiative to our adversaries. The battle has been joined and the United States intends to end the effort on its own terms. Will it be successful? Time will tell.

\section{Endnotes}

${ }^{1}$ Hedley Bull; quoted in Colin S. Gray, The Sheriff: America's Defense of the New World Order (Lexington: The University Press of Kentucky, 2004), 53. 
${ }^{2}$ George W. Bush, National Strategy for Combating Terrorism (Washington, D.C.: The White House, February 2003), 11.

${ }^{3}$ Bryan D. Brown, "U.S. Special Operations Command: Meeting the Challenges of the $21^{\text {st }}$ Century," Joint Forces Quarterly, Issue 40 ( $1{ }^{\text {st }}$ Quarter 2006): 39.

${ }^{4}$ Colin S. Gray, "Handfuls of Heroes on Desperate Ventures: When Do Special Operations Succeed?" Parameters, Spring 1999, [journal on-line]; available from https://carlislewww.army.mil/usawc/Parameters/99spring/gray.htm; Internet; accessed 18 December 2005.

${ }^{5}$ Bush, National Strategy for Combating Terrorism, 1.

${ }^{6}$ Samuel P. Huntington, American Military Strategy. Chester W. Nimitz Memorial Lecture. Policy Papers in International Affairs 28. Berkeley: Institute of International Studies, University of California, Berkeley, 1986; quoted in Colin Gray. The Sheriff: America's Defense of the New World Order (Lexington: The University Press of Kentucky, 2004), 106.

${ }^{7}$ Paul R. Kan, "National Security Strategy," lecture, U.S. Army War College, Carlisle Barracks, PA, 27 October 2005, cited with permission of Dr. Kan,

${ }^{8}$ George W. Bush, National Security Strategy (Washington, D.C.: The White House, 17 September 2002), 1.

${ }^{9}$ Randall A. Yim, "Combating Terrorism: Evaluation of Selected Characteristics in National Strategies Related to Terrorism", 3 February 2004; available from www.gao.gov/cgibin/getrpt?GAO-04-408T; Internet; accessed 2 January 2006.

${ }^{10}$ Ibid.

${ }^{11}$ Colin S. Gray, Explorations in Strategy (Westport: Praeger Publishers, 1996), 6.

${ }^{12}$ Ibid., 11.

${ }^{13}$ Bush, National Security Strategy, 5.

${ }^{14} \mathrm{Ibid}$.

${ }^{15} \mathrm{lbid}$.

${ }^{16}$ Bush, National Strategy for Combating Terrorism , 16, 17, 22, 28.

${ }^{17}$ Ibid., 11.

${ }^{18}$ Ibid., 13.

${ }^{19}$ lbid., 15.

${ }^{20} \mathrm{lbid}$. 
21 "National Military Strategic Plan for the Global War on Terrorism" 1 February 2006, available from; http://www.defenselink.mil/qdr/docs/2005-01-25-Strategic-Plan.pdf; Internet; accessed 27 February 2006.

${ }^{22}$ Linda Robinson, "Plan of Attack: The Pentagon has a secret strategy for taking on terrorists-and taking them down," U.S. News \& World Report, 1 August 2005, [journal on-line]; available from http://www.usnews.com/usnews/news/articles/050801/1terror.htm; Internet; accessed 1 December 2005.

${ }^{23}$ Ibid.

24 Ibid.

25 "SOF Core Tasks", 12 July 2005, linked from the College of Aerospace Doctrine, Research and Education Home Page available from http://www.cadre.maxwell.af.mil/ warfarestudies/wpc/wpc_txt/so/core.htm accessed 4 December 2005. 1. Counterterrorism (CT) This task involves offensive measures taken to prevent, deter, preempt, and respond to terrorism. 2. Counterproliferation (CP) of Weapons of Mass Destruction (WMD) - Actions taken to support DoD and other governmental agencies to prevent, limit, and/or minimize the development, possession, and employment of WMD...3. Direct Action (DA) - The conduct of short duration strikes and other small-scale offensive actions conducted as a special operation in hostile, denied or politically sensitive environments to seize, destroy capture, exploit, recover or damage designated targets of strategic or operational significance.4. Unconventional Warfare (UW) - a broad spectrum of military and paramilitary operations, normally of a long duration. UW is predominately conducted by, with, or through indigenous or surrogate forces... UW includes guerilla warfare and other direct offensive, low visibility, covert, or clandestine operations.5. Psychological Operations (PSYOP) - Planned operations to convey truthful information and indicators to foreign audiences to influence their emotions, motives, objective reasoning, and ultimately, the behavior of foreign governments, organizations, groups, and individuals...6. Foreign Internal Defense (FID) - Participation by civilian or military agencies of the government in any of the action programs taken by government or other designated organization to free their society from subversion, lawlessness, and insurgency. SOF's primary contribution to this interagency activity is to organize, train, advise, and assist host-nation military and paramilitary forces.7. Civil Affairs Operations (CAO) - ...Activities involve establishing and conducting military government or civil administration until civil authority or government can be restored or transitioned to other appropriate authorities.

${ }^{26}$ Dell L. Dailey and Jeffery G. Webb, "U.S. Special Operations Command and the War on Terror," Joint Forces Quarterly, Issue 40 (1 ${ }^{\text {st }}$ Quarter 2006): 46.

${ }^{27}$ Robinson.

${ }^{28}$ Unified Command Plan, available from http://www.dod.mil/specials/unifiedcommand/ index.html; Internet; accessed 27 February 2006.

${ }^{29}$ Carl von Clausewitz, On War, trans. Michael Howard and Peter Paret (Princeton, N.J.: Princeton University Press, 1989), 88.

${ }^{30}$ Bush, National Security Strategy, 15. 
${ }^{31}$ Daniel Benjamin and Steven Simon, The Age of Sacred Terror: Radical Islam's War Against America (New York: Random House Trade Paperback, 2003), 402.

${ }^{32}$ Colin S. Gray, Modern Strategy (Oxford: Oxford University Press, 1999), 339.

${ }^{33}$ Lee H. Hamilton, "Fighting Terrorism," Indiana Journal of Global Legal Studies (Summer 2005): [database on-line]; available from ProQuest; accessed 12 January 2006.

${ }^{34}$ Ibid.

${ }^{35}$ M. Elaine Bunn, "Preemptive Action: When, How, and to What Effect?" Strategic Forum, July 2003, [journal on-line]; available from http://www.ndu.edu/inss/press/

NDUPress_STRFOR.htm; Internet; accessed 13 January 2006.

${ }^{36}$ Bush, National Security Strategy, 15.

${ }^{37}$ Franklin Eric Wester, "Preemption and Just War: Considering the Case of Iraq", Parameters, Winter 2004-05 [journal on-line]; available from http://carlisle-www.army.mil/ usawc/Parameters/04winter/wester.htm; Internet, accessed 16 January 2006.

${ }^{38}$ Robert Kagan, Of Paradise and Power (New York, NY, Vintage Books, 2004), 140.

39 "Strategy for the War on Terrorism" The Cato Policy Report, July/August 2004, [journal on-line]; available from http://www.cato.org/pubs/policy_report/v26n4/cpr-26n4-1.pdf; accessed 4 December 2005

40 Ibid.

${ }^{41}$ Michael E. O’Hanlon, Susan E. Rice, and James B. Steinberg, "The New National Security Strategy and Preemption, Policy Brief \#113," 2002; available from http://www.brookings.edu/printme.wbs?page=/comm./policybriefs/pb113.htm; Internet; accessed 16 January 2006.

42 Kagan, 143.

${ }^{43}$ Clark A. Murdock et al., Beyond Goldwater-Nichols: U.S. Government and Defense Reform for a New Strategic Era, Phase 2 Report (Washington, D.C.: Center for Strategic and International Studies, 2005), 31; available from http://www.

csis.org/media/csis/pubs/bgn_ph2_report.pdf; Internet; accessed 2 January 2006.

${ }^{44}$ David Ignatius, "Bush's Clark Kent," The Washington Post (11 February 2005): [database on-line]; available from ProQuest; accessed 2 January 2006.

${ }^{45}$ Robinson.

46 "National Security Council Functions" linked from The White House Home Page, available from http://www.whitehouse.gov/nsc/; Internet; accessed 2 January 2006.

${ }^{47}$ Bert B. Tussing and Kent Hughes Butts, "Aligning the Interagency Process for the War on Terrorism," June 2005; available from http://www.carlisle.army.mil/usacsl//papers.asp; Internet 
${ }^{48}$ The White House, "History of the National Security Council, 1947-1997," available from http://www:whitehouse.gov/nsc/text/history.html; Internet; accessed 2 January 2006.

${ }^{49}$ Kent Hughes Butts and Jeffrey C. Reynolds, eds, The Struggle Against Extremist Ideology: Addressing the Conditions That Foster Terrorism (Carlisle, PA: USAWC Center for Strategic Leadership, 2005), 112.

${ }^{50}$ Murdock et al., 27

${ }^{51}$ Thomas H. Kean et al., "The 9/11 Commission Report", 21 August 2004; available http://www.9-11commission.gov/report/911Report_Ch13.htm; Internet; accessed 2 January 2006.

${ }^{52}$ Murdock et al.,44.

${ }^{53}$ George W. Bush, National Strategy for Combating Terrorism (Washington D.C.: The White House, February 2003), 22.

${ }^{54}$ Murdock et al., 26.

${ }^{55}$ Colin Gray. The Sheriff: America's Defense of the New World Order (Lexington, KY: The University Press of Kentucky, 2004), 114.

${ }^{56}$ Kean et al.

${ }^{57}$ P.L. 108-485, 17 December 2004, linked from United States Senate Homepage at "Active Legislation," available from http://www.senate.gov/pagelayout/legislative/

b_three_sections_with_teasers/active_leg_108.htm; Internet; accessed 2 January 2006.

${ }^{58}$ Richard A. Best, Jr., Alfred Cumming, and Todd Mase, "Director of National Intelligence: Statutory Authorities," 11 April 2005; available from http://www.fas.org/sgp/crs/intel/ RS22112.pdf; accessed 27 February 2006.

${ }^{59}$ Congressional Research Service, "Director of National Intelligence: Statutory Authorities," 11 April 2005; available from http://www.counterterrorismtraining.gov/pubs/05.html; Internet; accessed 2 January 2006.

${ }^{60}$ Lee H. Hamilton, "Fighting Terrorism," Indiana Journal of Global Legal Studies (Summer 2005): [database on-line]; available from ProQuest; accessed 12 January 2006.

${ }^{61}$ Kean et al.

${ }^{62}$ Kent Hughes Butts and Jeffrey C. Reynolds, eds, The Struggle Against Extremist Ideology: Addressing the Conditions That Foster Terrorism (Carlisle, PA: USAWC Center for Strategic Leadership, 2005), 115.

${ }^{63}$ For a set of definitions of terms surrounding the phenomenon of Globalization, see Thomas P. M. Barnett, Blueprint for Action: A Future Worth Creating (New York: G.P. Putnam's Sons, 2005), xv-xix. 
${ }^{64}$ Thomas L. Friedman, The World is Flat: A Brief History of the Twenty-First Century (New York: Farrar, Straus and Giroux, 2005), 391-392.

${ }^{65}$ Benjamin and Simon, 409.

${ }^{66}$ Bernard Lewis, The Crisis of Islam: Holy War and Unholy Terror (New York: Random House Trade Paperbacks, 2004), 113.

${ }^{67}$ Benjamin and Simon, 407.

${ }^{68}$ F. Gregory Gause III, "Can Democracy Stop Terrorism?" Foreign Affairs Volume 84, Number 5 (September/October 2005), 67.

${ }^{69}$ Bernard Lewis, The Crisis of Islam: Holy War and Unholy Terror (New York: Random House Trade Paperbacks, 2004), 167.

${ }^{70}$ Dailey and Webb, 45.

${ }^{71}$ Benjamin and Simon, 487. 